\title{
Do company strategies and structures converge in global markets? Evidence from the computer industry
}

Citation for published version (APA):

Hagedoorn, J., \& Duysters, G. M. (2001). Do company strategies and structures converge in global markets? Evidence from the computer industry. Journal of International Business Studies, 32, 347-356. https://doi.org/10.1057/palgrave.jibs.8490956

Document status and date:

Published: 01/01/2001

DOI:

10.1057/palgrave.jibs.8490956

Document Version:

Publisher's PDF, also known as Version of record

\section{Please check the document version of this publication:}

- A submitted manuscript is the version of the article upon submission and before peer-review. There can be important differences between the submitted version and the official published version of record.

People interested in the research are advised to contact the author for the final version of the publication, or visit the DOI to the publisher's website.

- The final author version and the galley proof are versions of the publication after peer review.

- The final published version features the final layout of the paper including the volume, issue and page numbers.

Link to publication

\footnotetext{
General rights rights.

- You may freely distribute the URL identifying the publication in the public portal. please follow below link for the End User Agreement:

www.umlib.nl/taverne-license

Take down policy

If you believe that this document breaches copyright please contact us at:

repository@maastrichtuniversity.nl

providing details and we will investigate your claim.
}

Copyright and moral rights for the publications made accessible in the public portal are retained by the authors and/or other copyright owners and it is a condition of accessing publications that users recognise and abide by the legal requirements associated with these

- Users may download and print one copy of any publication from the public portal for the purpose of private study or research.

- You may not further distribute the material or use it for any profit-making activity or commercial gain

If the publication is distributed under the terms of Article $25 \mathrm{fa}$ of the Dutch Copyright Act, indicated by the "Taverne" license above, 


\title{
Do Company Strategies and Stuctures Converge in Global Markets? Evidence from the Computer Industry
}

\author{
Geert Duysters* \\ EINDHOVEn CENTRE FOR INNOVATION STUDIES
}

John Hagedoorn** MERIT, UNIVERSITY OF MAASTRICHT

This note examines isomorphism and diversity in a global industry. We study how the ongoing internationalisation process has affected companies from various regions of the world. Empirical research is fo-

\section{INTRODUCTION}

The objective of this note is to detect whether a homogeneous, international environment creates a homogeneous group of companies, leading to what is known in the literature as organizational isomorphism (Meyer and Rowan, 1977; Hannan and Freeman, 1989; Dimaggio and Powell, 1983). Isomorphism was first described by Hawley (1968, p.334) who suggested that “. . . units subjected to the same environmental conditions .... acquire a similar form of organization." In other literatures the emergence of isomorphism is discussed in terms of cussed on the international computer industry. We find that companies in this sector have become more divergent and that there is little evidence of a process of isomorphism. two fundamental forces: adaptation and selection. Adaptation to changes in the environment materializes as firms try to increase their fit with the environment (Burns and Stalker, 1961; Lawrence and Lorsch, 1967). A better fit is thought to enhance the survival chances of companies in the long run. However, many companies also experience inertial pressures that frustrate adaptation. In a rapidly changing environment it is doubtful whether all organizations are changing quickly enough to increase their fit with a new environmental state. This slow process of adaptation is referred to as

\footnotetext{
${ }^{*}$ Geert Duysters is professor of Organisation Science at the Eindhoven University of Technology. He is scientific director of the Eindhoven Centre for Innovation Studies (ECIS)

** John Hagedoorn is professor of Strategic Management at Maastricht University and a professorial fellow with the Maastricht Economic Research institute on Innovation and Technology.
}

Earlier versions of this paper were presented at the EGOS conference-Maastricht,1998 and the 1999 Academy of Management Meeting in Chicago. We thanks participants at these conferences and the anonymous reviewers of this journal for their comments. 
relative inertia. Because of this relative inertia, selection forces are granted time to develop. Inspired by a Darwinian conception of natural selection many authors in the population ecology tradition (Aldrich, 1979; Caroll, 1987; Hannan and Freeman, 1989; Singh \& Lumsden, 1990) contend that organizations that are best adapted to a specific environment survive, while other, less adapted, organizations disappear.

Another important subject within the general discussion on organizational isomorphism is the possible mediating effect of inherited properties of organizations on their adaptation to environmental changes. Stinchcombe (1965) argues that social, cultural, technological and competitive conditions under which a company is established have a continuing effect on its strategy and structure. Although this imprintment thesis is discussed elaborately in the literature (Aldrich, 1979; Hannan and Freeman, 1984, and 1989; Tolbert and Zucker, 1983) there is no empirical research on the continuing effect of the domestic or regional background of companies on their behaviour and organization in an international environment.

This paper explores this continuing effect of international regional backgrounds of companies on their behaviour and structure. It not only gives attention to the international context of the competitive environment of firms, reflecting the importance of the internationalization of companies itself, it also incorporates the imprintment line of thinking in the literature.

\section{HYPOTHESES}

The literature suggests that the degree of isomorphism among companies is dependent on the impact of two fundamental drivers, i.e. adaptation and selection, whereas the effect of these drivers is related to the degree of competition within a specific organizational field. Increased competition is expected to raise the importance of both selection and adaptation. Under competitive conditions less fit organizations will decline and will eventually be excluded from the market. From an adaptation perspective, increasing competition raises the need for firms to adapt their structures and strategies to the specific demands of their environment. The degree of isomorphism is therefore positively related to the degree of competition in the market. Competition is, however, not the only important factor of isomorphism. Whether isomorphism among organizations takes place is also dependent on the homogeneity of the environment (Hawley,1968).

Contrary to multi-domestic markets, global markets can be seen as examples of homogeneous environments, where the conditions in which companies operate are similar in terms of products, major competitors and the rate of technological development. Thus, if isomorphism takes place, we should be able to detect it in highly competitive global markets. However, the ability of firms to respond to certain changes in the environment is often dependent upon patterns of behavior they tended to exploit in the past (Nelson and Winter, 1982). As argued in the above, companies often suffer from inertia, which makes it difficult for them to lose their original characteristics in favour of a truly global orientation. Following Stinchcombe's (1965) imprintment theory, we expect firms to be particularly affected by their original backgrounds, as experienced during the first stage of their organizational life cycle when they are learning 'the tricks of the trade' and the rules of competition in their regional markets. As 
a consequence these conditions become imprinted in their organizational structure and their behaviour (Boeker, 1988). This line of analysis coincides with the ideas of $\mathrm{Hu}$ (1992) and Porter (1986 and 1990) who argue that in spite of their international activities, most companies can still be identified by their regional backgrounds. Hence:

Hypothesis 1: The structures and strategies of companies operating in a global environment can still be identified with regard to their regional backgrounds.

However, we can also expect that, because of the ongoing globalization tendencies (see e.g. Dunning, 1988 and 1993; Duysters and Hagedoorn, 1996; Reich, 1991), firms tend to become gradually more isomorphic over time. From this perspective, globalization is an ongoing process that will eventually lead to a single global world market in which companies have become footloose (Reich, 1991) as they have no particular relationship to any specific country or region. Therefore:

Hypothesis 2: Over time patterns of isomorphism amongst companies, in terms of their structural and strategic features, are likely to become stronger.

\section{Data And Methodology}

The hypotheses will be evaluated on the basis of structural and strategic (dis) similarities among companies that are participating in a highly competitive global environment. We focus on companies in the international computer industry because this industry is characterized by global competition among companies that are well known for their international market orientation and their globally dispersed facilities. The second reason to study the computer industry is its highly competitive nature.

To analyse general patterns of isomorphism and diversity we will evaluate the strategies and structures of firms from Europe, Asia and the USA for the period 1986-1993. This population includes 36 US companies, 5 European companies and 15 Asian (mainly Japanese) companies, which collectively account for about $70 \%$ of the international computer market.

Our analysis of a period of eight years enables us to assess whether and to what degree isomorphism takes place and to detect whether possible patterns of isomorphism increase over time. If high levels of isomorphism can be found among the companies from different regions, this would support the view that globally operating companies have converged into similar structures and strategies. On the other hand, if companies can still be clearly identified by their regional background, this would indicate that organisations are still influenced by their local environment. In that case, isomorphism is only found at the regional level.

For the empirical analyses we use a number of variables related to the structure and strategy of companies, as suggested by Stinchcombe (1965), that are used in many studies in the management and organization literature:

- Two standard operational constructs are used to detect differences or similarities in the structure of organizations: size and specialization. As an indicator for size we use the natural logarithm of the average revenues of companies obtained from the computer industry (SIZE). Size is an important indicator for differences between companies with respect to 
their organizational complexity, their span of control and the way they do their business. The degree of specialization (SPECIALIZATION) indicates the share of computer sales in total corporate sales. Specialization thus indicates the degree to which companies are specialized in computers, or are diversified.

- In high technology industries such as the computer industry a firm's competitive strategy is to a large degree dependent on its technology strategy. Therefore we focus on measures related to the technology strategy of the various companies.

- The relative innovative strength of companies is indicated by their number of US computer patents divided by their computer revenues (PATENTINTENSITY). The R\&D intensity of firms is measured as their computer-related R\&D expenditures as a percentage of computer sales (RDINTENSITY). Apart from these two standard innovation strategy indicators we consider two measures that are related to the external acquisition of technology. Previous research (Hagedoorn and Duysters, 1997) has shown that firms use different strategies to acquire technology externally using M\&As, alliances, or a mixed strategy. The strategic technology alliance intensity (STA-INTENSITY) indicates the number of computer-related strategic technology alliances divided by the computer revenues. The other external technology appropriation related indicator is the M\&A intensity (MA-INTENSITY) which indicates the relative degree to which firms use $M \& A s$ in computers as a means to acquire technological capabilities (computer-related M\&As divided by computer revenues). The last variable associated with the technology strategy of firms is the technology specialization (TECHSPECIALIZATION) index which measures the amount of computer-related patents divided by the total number of patents.

- The final variable used in the analysis refers to the internationalization strategy of companies (INTERNATIONALIZATION) indicated by the relative share of sales outside the region of origin (Europe, the US or Asia) in total sales. (See the Appendix for information about the sources of the data.)

\section{Analysis of Patterns of Diversity AND ISOMORPHISM}

To reveal patterns of diversity or isomorphism we applied discriminant function analysis using the region of origin of firms (REGION) as a categorical, dependent variable. The starting point for our analysis is the evaluation of the mean scores on the individual variables of companies from different regions. We performed a 'one-way' ANOVA to measure whether group means of independent variables differ significantly. As our study refers to three groups (regions) a 'normal' T-test study, which is only capable of dealing with two groups, could not be performed. In addition to the ANOVA we apply the so-called Scheffe test because the sizes of the groups are not equal. The Scheffe test makes use of the differences between means to calculate an F-ratio (see table 1).

The results indicate that group means are not equal in the case of the specialization of companies as computer manufacturers, their computer patent intensity or their technological specialization. The other five variables (overall size, $\mathrm{R} \& \mathrm{D}$ intensity, $\mathrm{M} \& \mathrm{~A}$ intensity, STA in- 


\begin{tabular}{|c|c|c|}
\hline TES & $\begin{array}{l}\text { E } 1 \\
\text { OF GROUP ME }\end{array}$ & \\
\hline Variable & Wilks' Lambda & $\mathrm{F}$ \\
\hline DPSIZE & .941 & 1.673 \\
\hline SPECIALIZATION & .894 & $3.139 *$ \\
\hline PATENTINTENSITY & .839 & $5.066 * *$ \\
\hline RDINTENSITY & .937 & 1.791 \\
\hline MA-INTENSITY & .990 & 0.276 \\
\hline STA-INTENSITY & .986 & 0.368 \\
\hline TECHSPECIALIZATION & .773 & $7.783 * * *$ \\
\hline INTERNATIONALIZATION & .971 & 0.780 \\
\hline \multicolumn{3}{|l|}{$\mathrm{N}=56$} \\
\hline \multicolumn{3}{|c|}{${ }^{*} \mathrm{p}<0.10 \quad{ }^{* *} \mathrm{p}<0.05 \quad * * * \mathrm{p}<0.01$} \\
\hline
\end{tabular}

tensity, and internationalisation) show relatively high Wilks' Lambda values with insignificant results for different regions. This implies that in the international computer industry, isomorphism does not seriously affect three major structural and strategic variables. To assess the overall discriminatory power of the total set of variables, we consider the goodness of fit of the discriminant functions. We find a Chi square value of 30.488 and a corresponding significance of 0.016 which implies that mean scores on the combined variables are not equal for companies from different regions.

These findings indicate that companies from different regions do diverge with respect to a number of variables; however we still need to assess whether companies operating in a global environment can be identified with regard to their original regional backgrounds. In order to test hypothesis 1, we classified all cases according to their scores on the combined discriminant functions. ${ }^{1}$ This procedure resulted in a correct classification of 78.6 percent of the cases (see Table 2). This indicates that we can still identify the home region of a large number of organizations on the basis of their scores on the various indicators. Table 2 reveals that companies from the USA and from Asian countries are largely identifiable in terms of their home re-

\begin{tabular}{|lcccr|}
\hline \multicolumn{5}{|c|}{ TaBle 2 } \\
\hline \multicolumn{5}{|c|}{ Classification ReSUlts (1986-1993) } \\
\hline \multicolumn{5}{|c|}{ Predicted Group Membership } \\
\hline Region & USA & Asia & Europe & Total \\
\hline USA & $33(91.7 \%)$ & $3(8.3 \%)$ & $0(.0 \%)$ & $36(100 \%)$ \\
Asia & $4(26.7 \%)$ & $10(66.7 \%)$ & $1(6.7 \%)$ & $15(100 \%)$ \\
Europe & $3(60 \%)$ & $1(20 \%)$ & $1(20 \%)$ & $5(100 \%)$ \\
Ungrouped Cases & $1(100 \%)$ & $0(.0 \%)$ & $0(.0 \%)$ & $1(100 \%)$ \\
\hline $78.6 \%$ of original grouped cases correctly classified & & \\
\hline
\end{tabular}




\begin{tabular}{|lcccr|}
\hline \multicolumn{5}{|c|}{ Table 3A } \\
\hline \multicolumn{5}{|c|}{ Classification RESUlts (1986-1989) } \\
\hline Region & Predicted Group Membership \\
\hline USA & USA & Asia & Europe & Total \\
Asia & $31(93.9 \%)$ & $2(6.1 \%)$ & $0(.0 \%)$ & $33(100 \%)$ \\
Europe & $5(38.5 \%)$ & $8(61.5 \%)$ & $0(.0 \%)$ & $13(100 \%)$ \\
Ungrouped Cases & $5(100 \%)$ & $0(.0 \%)$ & $0(.0 \%)$ & $5(100 \%)$ \\
& $2(100 \%)$ & $0(.0 \%)$ & $0(.0 \%)$ & $2(100 \%)$ \\
\hline $76.5 \%$ of original grouped cases correctly classified & & \\
\hline
\end{tabular}

gions. Hypothesis 1 can therefore not be rejected.

In order to test hypothesis 2 we perform two discriminant function analyses, one for the period 1986-1989 and one for 1990-1993. According to a number of studies, international competition in this industry increased in the first period (see e.g. Flamm, 1988; Dunning, 1988; Cantwell, 1991) and then accelerated during the second period (see e.g. Mansell, 1993). Comparing Tables 3a and $3 \mathrm{~b}$ enables us to detect possible increasing isomorphism tendencies over time.

Those Tables show that the percentage of correctly classified cases decreased from 76.5 percent during the first period to 75.9 percent during the second period.
This could be an indication of a very slightly higher degree of isomorphism over time.

Further analysis, however, is necessary to address the question which variables might have become more or less isomorphic over time. Contrary to what was indicated by the percentages of correctly classified cases, the desaggregated analysis does not point to increasing isomorphism. Tables $4 \mathrm{a}$ and $4 \mathrm{~b}$ show that companies from different home countries remained different in terms of their degree of specialization in computers, their innovative strength, and their technological specialization. These companies have even diverged further in terms of their international orientation and R\&D intensity. Table 4c shows that

\begin{tabular}{|lcccr|}
\hline \multicolumn{5}{|c|}{ TABLE 3B } \\
\hline \multicolumn{5}{|c|}{ Classification ReSUlts (1990-1993) } \\
\hline \multicolumn{5}{|c|}{ Predicted Group Membership } \\
\hline Region & USA & Asia & Europe & Total \\
\hline USA & $29(85.3 \%)$ & $5(14.7 \%)$ & $0(0 \%)$ & $34(100 \%)$ \\
Asia & $3(20 \%)$ & $11(73.3 \%)$ & $1(6.7 \%)$ & $15(100 \%)$ \\
Europe & $3(60 \%)$ & $1(20 \%)$ & $1(20 \%)$ & $5(100 \%)$ \\
Ungrouped Cases & $1(50 \%)$ & $1(50 \%)$ & $0(.0 \%)$ & $2(100 \%)$ \\
\hline $75.9 \%$ of original grouped cases correctly classified & & \\
\hline
\end{tabular}




\begin{tabular}{|c|c|c|}
\hline \multicolumn{3}{|c|}{$\begin{array}{c}\text { Table 4A } \\
\text { Tests of EQuality OF Group Means (1986-1989) }\end{array}$} \\
\hline Variable & Wilks' Lambda & $\mathrm{F}$ \\
\hline DPSIZE & .918 & 2.154 \\
\hline SPECIALIZATION & .753 & $8.020 * * *$ \\
\hline PATENTINTENSITY & .742 & $8.507 * * *$ \\
\hline RDINTENSITY & .971 & .732 \\
\hline MA-INTENSITY & .990 & .258 \\
\hline STA-INTENSITY & .988 & .300 \\
\hline TECHSPECIALIZATION & .904 & $2.61 *$ \\
\hline INTERNATIONALIZATION & .998 & .058 \\
\hline \multicolumn{3}{|l|}{$N=56$} \\
\hline
\end{tabular}

US companies in particular, and European firms to a lesser extent, have become more inward oriented over time, whereas Asian companies have become more outward oriented in terms of their sales. In terms of their R\&D intensiveness US companies in particular, and European companies to a lesser extent, have become more $R \& D$ intensive over time, whereas Asian firms have become less R\&D intensive.

It is clear from these findings that with respect to the individual variables, hy- pothesis 2 is not supported by our research. A further explanation of these differences and changes is clearly beyond the exploratory scope of this research note, which mainly explores the basic trends in possible isomorphism. Future in-depth study of these variables, supported by more detailed information on companies, will be necessary to provide an explanation for this lack of isomorphism or convergence. However, the main findings of the present paper suggest that a pattern of isomorphism was not evident.

\begin{tabular}{|c|c|c|}
\hline \multicolumn{3}{|c|}{$\begin{array}{c}\text { TABle } 4 B \\
\text { Tests of Equality OF Group Means (1990-1993) }\end{array}$} \\
\hline Variable & Wilks' Lambda & $\mathrm{F}$ \\
\hline DPSIZE & .957 & 1.153 \\
\hline SPECIALIZATION & .845 & $4.879 * *$ \\
\hline PATENTINTENSITY & .879 & $3.661 * *$ \\
\hline RDINTENSITY & .869 & $4.012 * *$ \\
\hline MA-INTENSITY & .989 & .302 \\
\hline STA-INTENSITY & .982 & .476 \\
\hline TECHSPECIALIZATION & .805 & $6.408^{* * *}$ \\
\hline INTERNATIONALIZATION & .869 & $3.994 * *$ \\
\hline \\
\hline
\end{tabular}




\begin{tabular}{|llll|}
\hline \multicolumn{4}{|c|}{ TABLE 4C } \\
Group Means Per REgION \\
\hline Variable & USA & ASIA EUROPE \\
\hline Internationalization & & & \\
P1 & 0.64 & 0.65 & 0.63 \\
P2 & 0.55 & 0.69 & 0.59 \\
R\&D Intensity & & & \\
P1 & 0.086 & 0.081 & 0.065 \\
P2 & 0.090 & 0.065 & 0.067 \\
\hline P1 $=1986-1989$ & & & \\
P2 $=1990-1993$ & & & \\
\hline
\end{tabular}

\section{Conclusions}

Despite some degree of convergence for specific characteristics of companies, divergence of companies is still an important phenomenon in this global industry. Forces leading to isomorphism have not yet become apparent. Companies remain less global than expected, still sharing imprinted strategic and structural features for an extended period of time after they have become internationally oriented. Our analysis also rejects the hypothesis that in a highly competitive global industry firms would gradually become isomorphic in terms of both structure and strategy. The degree of imprintment in this industry has not significantly decreased over time. On the contrary, the amount of divergence, with respect to individual variables, among companies from different regions has increased somewhat.

The variation in the population at large as well as within the three regions does not suggest a deterministic relationship between environment and the individual organization. Turning briefly to a more theoretical level of discussion, we can point to an interpretation of external and internal influences on the formation of company characteristics that shares a number of major theoretical traits with evolutionary theory in the economics and business literature. Contributions from this line of theory devote more attention to intra-population variance than either the organizational population ecology theory or the orthodox economic theory of the firm (Nelson and Winter, 1982 and Winter, 1990). The perception of firm heterogeneity, in terms of size and strategy for instance, as well as differences in organizational fitness of companies, are major theoretical building blocks in this approach. Following Winter (1990) we can interpret the observed variations in this international industry as partly reflecting the different environments they encountered in early and later stages of their development. Also, the variation in structure and strategy is not fully reflecting the inherited properties because there is some degree of convergence (or at least non-significant divergence) with regard to aspects of technological strategies that are so crucial to this high-tech industry. In that sense, our findings that reject a straightforward isomorphic, deterministic interpretation of organizational aspects of company behaviour suggest a more phenotype-like interpretation of the variation among a population of companies. In such a nondeterministic and evolutionary understanding of organizational development and inter-firm heterogeneity, companies are jointly determined by their inherited properties and the environmental conditions which they face through competition in changing markets.

\section{Note}

1. One firm is ungrouped because it is not part of the analysis, it does not fit into the country classification. In this case ungrouped refers to a company from Canada. 


\section{REFERENCES}

Aldrich, H.E. 1979. Organizations \& Environments. Englewood Cliffs: Prentice-Hall Inc.

Boeker, W.P. 1988. Organizational Origins: Entrepreneurial and Environmental Imprinting at the Time of Founding. In Carroll, G.R. Ecological Models of Organizations. Cambridge: Ballinger Publishing Company.

Burns,T. \& Stalker, G.M. 1961. The Management of Innovation. London: Tavistock.

Cantwell, J. (1991), 'The International Agglomeration of R\&D', in M. Casson (ed.), Global Research Strategy and International Competitiveness, Blackwell, Oxford.

Carroll, G.R. 1987. Publish and Perish: The Organizational Ecology of Newspaper Industries. Greenwhich: JAI Press.

Dimaggio, p.J. \& Powell, W.W. 1983. The Iron Cage Revisited: Institutional Isomorphism and Collective Rationality in Organizational Fields. American Sociological Review. 48: 147-160.

Dunning, J.H. 1988. Multinationals, Technology and Competitiveness. London: Unwin Hyman.

1993. Multinational Enterprises and the Global Economy. Wokingham: Addison-Wesley.

Duysters, G. \& J. Hagedoorn. 1996. Internationalization of Corporate Technology through Strategic Partnering: an Empirical Investigation, Research Policy, 25(1): 1-12.

Flamm, K. (1988), Creating the Computer: Government, Industry, and High Technology, The Brookings Institute, Washington.

Gartner Group. 1995. Yardstick Worldwide Top 100 Computer Companies.

Hagedoorn, J. \& Duysters, G. 1997. External Appropriation of Innovative Capabilities: The Choice Between
Strategic Partnering and Mergers and Acquisitions, paper presented at the 1997 Academy of Management Meeting, Boston.

Hannan, M.T. \& Freeman, J. 1984. Structural Inertia and Organizational Change. American Sociological Review. 49:149-64.

\& 1989. Organizational

Ecology. Cambridge: Harvard University Press.

Hawley, A. 1968. Human Ecology in: Sills, D.L. (ed.) International Encyclopaedia of the Social Sciences. pp. 328337. New York: Macmillan.

$\mathrm{Hu}$, Y.S. 1992. Global or Transnational Corporations and National Firms with International Operations. California Management Review. 34: 107-127.

IFR Securities. 1995, IFR Securities Database, London.

Lawrence, p.R. \& Lorsch, J.W. 1967. Organization and Environment. Boston: Harvard Business School Press.

Mansell, R. 1993, The New Telecommunications: A Political Economy of Network Evolution, Sage Publications, Newbury Park, London.

MERIT. 1998, CATI data bank, Maastricht.

Meyer, J.W. \& Rowan, B. 1977. Institutionalized Organizations: Formal Structure as Myth and Ceremony. American Journal of Sociology. 83: 340-63.

Nelson, R.R. \& S.G. Winter. 1982. An Evolutionary Theory of Economic Change. Cambridge: Belknap Press.

Porter, M.E. 1986. Competition in Global Industries. Boston: Harvard Business School Press.

1990. The Competitive Advantage of Nations. New York: Free Press.

Reich, R.B. 1991. The Work of Nations, New York: Vintage Books. 
Singh, J.V. \& Lumsden, C.J. 1990. Theory and Research in Organizational Ecology. Annual Review of Sociology. 16: 161-95.

Stinchcombe, A.L. 1965. Social Structure and Organizations. In: March, J.G. (ed.), Handbook of Organizations. Chicago: Rand McNally.

Tolbert, p.S. \& Zucker, L.G. 1983. Institutional Sources of Change in the Formal Structure of Organizations: The
Diffusion of Civil Service Reform, 1880-1935. Administrative Science Quarterly, 28:22-39.

USPO (1998), Patent and Trademark Office database.

Winter, S.G. 1990. Survival, Selection, and Inheritance in Evolutionary Theories of Organizations. In Singh, J.V. Organizational Evolution - New Directions. Newbury Park: Sage: 269297.

\section{Appendix-Data Sources}

Data for size of companies, R\&D expenditures, international sales, specialization and region of origin is taken from the Gartner Groups annual Yardstick word-wide top 100 computer companies (Gartner Group 1995).

Data on patents is taken from the US Patent and Trademark Office database (USPO, 1998). We took the number of patents that firms applied for in SIC code 357 (computer and office equipment), which not only covers computers in a narrow sense but also includes peripheral equipment, storage devices and terminals.

The data on strategic technology alli- ances is derived from the MERIT-CATI data bank (MERIT 1998). This database contains information on cooperative agreements and on companies participating in these agreements. The transfer of technology or joint research is considered as crucial to these arrangements.

Data on M\&As is taken from a Securities Data M\&A database (Securities, 1995). This data base has information on the year the M\&A was established, the acquirer, the target, the parent acquirer and the parent target firm. Industry information is provided in SIC codes of the aquiree and acquirer. 